\title{
Concentration and motility of spermatozoa and testosterone level of kacang goat after seminal vesicle extract administration
}

Teuku Armansyah ${ }^{1}$, Edi Rusmansyah Putra Barat ${ }^{2}$, Cut Vela Risqa Handini ${ }^{2}$, Dwinna Aliza ${ }^{3}$, Amalia Sutriana ${ }^{1}$, Hamdan Hamdan ${ }^{4}$, Budianto Panjaitan ${ }^{5}$, Arman Sayuti ${ }^{5}$ and Tongku Nizwan Siregar ${ }^{4, *}$

${ }^{1}$ Pharmacology Laboratory, Faculty of Veterinary Medicine, Syiah Kuala University, Banda Aceh, Indonesia

${ }^{2}$ Veterinary Study Program, Faculty of Veterinary Medicine, Syiah Kuala University, Banda Aceh, Indonesia

${ }^{3}$ Pathology Laboratory, Faculty of Veterinary Medicine, Syiah Kuala University, Banda Aceh, Indonesia

${ }^{4}$ Reproduction Laboratory, Faculty of Veterinary Medicine, Syiah Kuala University, Banda Aceh, Indonesia

${ }^{5}$ Clinic Laboratory, Faculty of Veterinary Medicine, Syiah Kuala University, Banda Aceh, Indonesia

\begin{abstract}
This study aimed to determine the effect of seminal vesicle extract administration to increase the concentration and motility of spermatozoa and testosterone level of kacang goat. The experiment was arranged using a randomly completely block design (RCBD). Three kacang goats were used and each goat received three treatments namely P0 ( $2 \mathrm{~mL}$ of $0.9 \% \mathrm{NaCl}), \mathrm{P} 1$ (1.5 mL Capriglandin, PGF2 $\alpha$ ), and P2 (2 mL of seminal vesicle extract, EVS). Semen and blood were collected two days post-treatment to measure the concentration and motility of spermatozoa and testosterone level. Testosterone levels were measured with enzyme-linked immunosorbent assay (ELISA). Duration between treatments was one week after semen collection. The result showed that the average spermatozoa concentration $\left(\mathrm{x} 10^{6}\right)$ in $\mathrm{P} 0$; $\mathrm{P} 1$; and $\mathrm{P} 2$ respectively were $2,763.0 \pm 395.0 ; 2,060.00 \pm 678.2$; and 2,387.0 4442.7 (P>0.05), while the spermatozoa motility score in $\mathrm{P} 0 ; \mathrm{P} 1$; and $\mathrm{P} 2$ respectively were $3.7 \pm 1.1,3.4 \pm 0.5$, and $3.4 \pm 0.5(\mathrm{P}>0.05)$. The mean testosterone levels in $\mathrm{P} 0, \mathrm{P} 1$, and $\mathrm{P} 2$ respectively were $10.27 \pm 5.42,18.51 \pm 19.46$, and $29.57 \pm 12.96 \mathrm{ng} / \mathrm{mL}$ $(\mathrm{P}<0.05)$. It can be concluded that administration of EVS did not increase concentration and motility of spermatozoa but increased the level of testosterone in kacang goat.
\end{abstract}

Keywords: Kacang goat, PGF2 $\alpha$, Seminal vesicle extract, Spermatozoa, Testosterone.

\section{Introduction}

One of the supporting factors in optimizing the artificial insemination (AI) program in goats is the availability of frozen semen that meets minimum standards. Frozen semen has an advantage that it can be used for a long period of time, but has disadvantage of declining quality over freezing it. The decline in the quality of semen is significantly high, i.e. about $50 \%$ of sperm will die during freezing and the surviving sperm generally have low fertility (Lessard et al., 2000).

Kacang goat, one of Indonesia local goat shows low sperm quality compared to other local goats. Hanum $e t$ al. (2012) reported that sperm concentration in young kejobong goats is higher than in kacang goats with concentration of $79.44 \times 10^{8} / \mathrm{mL}$ and $58.94 \times 10^{8} / \mathrm{mL}$, respectively. However, the sperm concentration of kacang goat is higher than Boer goats with concentrations of $3,893 \times 10^{6} / \mathrm{mL}$ and $2,975 \times 10^{6} / \mathrm{mL}$, respectively (Pamungkas et al., 2008). Furthermore, Rachmawati et al. (2011) reported lower kacang goat spermatozoa motility compared to Etawa breed goat with sperm motility of $42.22 \pm 16.41 \%$ and $65.56 \pm 9.17 \%$, respectively. The quality of spermatozoa is influenced by testosterone levels. Testosterone is a steroid hormone of cholesterol molecule precursor derivate and is secreted by Leydig cells under the influence of luteinizing hormone (LH) which also act as an important reproductive hormone in males (Sherwood, 1995). Low testosterone levels can lead to decline in the quality of spermatozoa caused by one of the testosterone roles in spermatozoa maturation (Cornwall, 2009). Rachmawati et al. (2011) proved that there is a correlation between testosterone levels with libido and sperm quality, i.e. the higher the testosterone level, the higher the libido and sperm quality.

Quality of spermatozoa is generally improved by administration of prostaglandin F2 alpha (PGF2 $\alpha$ ). PGF2 $\alpha$ hormone can improve the quality of spermatozoa, but this practice is limited by its availability in local markets and expensive prices (Siregar et al., 2014). The use of PGF2 $\alpha$ in improving spermatozoa quality is still polemic. In cattle, sheep, pigs, and horses, the PGF2 $\alpha$ hormone was proven to improve the quality of spermatozoa (Hess, 2002). However, PGF2 $\alpha$ administration did not affect the quality of spermatozoa in dog (Traas and Kustritz, 2004). The difference results were suspected due to the difference in species and breed strains.

*Corresponding Author: Tongku Nizwan Siregar. Reproduction Laboratory, Faculty of Veterinary Medicine, Syiah Kuala 
To overcome the problem of PGF2 $\alpha$ use, another alternative is invented by using seminal vesicle extract (EVS). Seminal vesicle is one of organ or tissue that can secrete PGF2 $\alpha$. Gonzales (2001) stated that human semen contains large amounts of prostaglandins produced in seminal vesicles and is identified in high concentrations under vasectomy conditions. Pemayun et al. (2008) noted that EVS may lyse the corpus luteum (CL) of mare as indicated by decrease in progesterone levels up to $73 \%$ within 24 hours. Syafruddin et al. (2010) reported that administration of $5 \mathrm{~mL}$ of intra uterine EVS may induce libido in local goats. This indicates that levels of PGF2 $\alpha$ in the seminal vesicles are relatively high.

Siregar et al. (2014) reported an increase in the quality of spermatozoa and testosterone hormones after administration of seminal vesicle extract in white mice. Saifudini et al. (2005) reported an increase in sheep testosterone levels and spermatozoa quality after induction with PGF2 $\alpha$. Base on aforementioned studies, it was assumed that EVS administration may improve the spermatozoa quality and testosterone level in kacang goat.

Recently, no information are available regarding the effect of seminal vesicles extract in improving sperm quality and testosterone levels of kacang goat. Therefore, this study was carried out to determine the effect of seminal vesicle extract administration to increase the concentration and motility of spermatozoa and testosterone level of kacang goat.

\section{Materials and Methods}

The experiment employed a randomized complete block design with $3 \times 3$ Latin rectangular. Three kacang goats aged \pm 1.5 years were used and each goat was intramuscularly injected with $2 \mathrm{~mL}$ physiologic $\mathrm{NaCl}$ (negative control, P0), 2 mL PGF2 $\alpha$ (Capriglandin ${ }^{\circledR}$, positive control, P1), and $2 \mathrm{~mL}$ EVS (P2) for three weeks with 1 week interval between treatment. Semen and blood samples of 3 goats were collected from 2 days after each treatment $(n=3$ per week). Total sample of semen and blood collected for 3 weeks was 9 samples each.

\section{Extraction of Seminal Vesicle}

Seminal vesicle was collected from a slaughterhouse in Banda Aceh. Fat were removed before the seminal vesicle was sliced as thin as possible and was immersed for 24 hours in methanol. Supernatant were taken and dried using rotary evaporator. Then, $10 \mathrm{mg}$ of carboxyl methyl cellulose (CMC) was added in the $2.5 \mathrm{~g}$ of dried supernatant and dissolved in $25 \mathrm{~mL}$ of physiologic $\mathrm{NaCl}$ for 5 min at $37-40^{\circ} \mathrm{C}$ to obtain $10 \%$ concentration of seminal vesicle. As much as $2 \mathrm{~mL}$ seminal vesicle was then injected to goat.

\section{Motility of Spermatozoa Mass}

Semen was collected using artificial vagina weekly for 3 weeks. The semen was dropped on object glass, covered by cover glass and motility observed with light microscope in 400x magnification (Olympus CX21). Mass motility interpretation grouped into number, $0=$ immotile or immobile spermatozoa; $1=$ rotating spermatozoa; 2 swinging or circling of spermatozoa that are less than $50 \%$ progressive moves and no wave formation; 3 = moving progressively and producing mass movement around $50-80 \%$ of spermatozoa; $4=$ moving agile and forming visible wave around $90 \%$ of spermatozoa, and $5=$ moving very progressive with a rapid wave showing $100 \%$ of spermatozoa (Toelihere, 1985).

\section{Spermatozoa Concentration}

Spermatozoa concentrations were calculated using hemocytometer method (WHO, 1999). The diluted spermatozoa suspension is filled into an erythrocyte pipette until hitting 0.5 mark. Furthermore, a 3\% $\mathrm{NaCl}$ solution is collected using erythrocyte pipette until reaching 101 marks. Then, the solution was homogenized by moving it in number 8 pattern for 2-3 minutes. A few drops were removed and the solution was re- homogenized, then one drop of solution was placed on object glass and examined under microscope. The spermatozoa concentrations were calculated in the Neubauer count chamber by using formula: $\mathrm{N}=$ (400/80) x Y x 200 x 10 (Toelihere, 1985).

\section{Serum Collection}

Blood collection was performed at the same time of semen collection. Blood was collected through jugular vein of goats using disposable $3 \mathrm{~mL}$ syringe. Blood was inserted into the venoject tube, was then tilted at $45^{\circ}$ angle, and was left for several minutes. The blood was then centrifuged at $2500 \mathrm{rpm}$ for 15 minutes. Then the serum was put into the microtube, and was stored in a freezer at $-20^{\circ} \mathrm{C}$ until use.

\section{Testosterone Level Measurement}

Hormone measurement followed the procedures contained in the testosterone kit manual (ELISA DRG testosterone ELISA Kit, DRG Instruments $\mathrm{GmbH}$, Germany). A total of $25 \mu \mathrm{L}$ standard solutions, controls, and samples were put into each microplate well. Then $200 \mu \mathrm{L}$ enzyme conjugate was added, covered with cling film, homogenized by swinging it gently for 10 seconds, and incubated at room temperature for $60 \mathrm{~min}$. After incubation, each microplate well was washed with $300 \mu \mathrm{L}$ washing solution for 3 times using a microplate strip washer tool. Subsequently, $200 \mu \mathrm{L}$ substrate solution of tetra methyl benzine (TMB) was added to each well, then covered with cling film, and incubated at room temperature for 15 minutes. The enzymatic reaction was stopped by adding $100 \mu \mathrm{L}$ stop solution (H2SO4 $0.5 \mathrm{M}$ ) into each well. The absorbance was read using ELISA reader at $450 \mathrm{~nm}$ wavelength. Intra- and interassay coeficient of variation percentages were 4.86$5.18 \%$ and $5.74-7.84 \%$, respectively. 


\section{Data Analysis}

Spermatozoa concentration and motility as well as testosterone level were analyzed using two-way ANOVA with significance level of $\mathrm{p}<0.05$.

\section{Results and Discussion}

The results of spermatozoa concentration and motility as well as testosterone levels of kacang goat were presented in Table 1. Based on the statistical tests, administration of PGF $2 \alpha$ and EVS have no effect $(\mathrm{P}>0.05)$ on spermatozoa concentration. This result is in accordance with the results of Siregar et al. (2014) who reported that spermatozoa concentrations are not affected by the administration of EVS in white mice. Nevertheless, the concentration of kacang goat spermatozoa is relatively similar compared to most goats spermatozoa ranging from $2-6 \times 10^{9} / \mathrm{mL}$ of semen (Hafez, 2000). Failure in increasing spermatozoa concentrations in this study was likely due to the long interval (two days) between PGF2 $\alpha$ administration and spermatozoa collection. In other studies, semen collection was carried out 30 minutes after PGF2 $\alpha$ administration significantly improve the spermatozoa concentration (Kreider et al., 1981; Hashizume and Niwa, 1984; Mekonnen et al., 1989; Estienne and Harper, 2004; Olfati et al., 2013). However, in study conducted by Capitan et al. (1990) who performed semen collection one hour after PGF2 $\alpha$ administration and seven days after the last PGF2 $\alpha$ injection (post treatment) did not able to increase spermatozoa concentration. The difference in result is most likely related to the difference in livestock used and the collection method after PGF $2 \alpha$ administration. The results of this study indicate that administration of PGF $2 \alpha$ and EVS tends to decrease spermatozoa concentration. Similarly, Kreider et al. (1981) showed that administration of PGF2 $\alpha$ decrease the number of spermatozoa in horses. In contrast, Hafs et al. (1974) reported that administration of PGF $2 \alpha$ may increase the number of spermatozoa in the ductus deferens and may be related to an increase in spermatozoa movements out of the epididymal duct (Hess, 2002; Estienne and Harper, 2004). These difference results are probably due to differences in animals used, affecting its response to PGF2 $\alpha$ and EVS.

Table 1. Concentration and spermatozoa motility score and testosterone levels of kacang goat (mean $\pm \mathrm{SD}$ ) after EVS.

\begin{tabular}{lccc}
\hline \multirow{2}{*}{ Criteria } & \multicolumn{3}{c}{ Treatment } \\
\cline { 2 - 4 } & Control (P0) & PGF2 $\alpha(\mathrm{P} 1)$ & EVS (P2) \\
\hline Spermatozoa & $2,763.0$ & $2,060.0$ & $2,387.0$ \\
concentration $\left(10^{6}\right)$ & $\pm 395.0^{\mathrm{a}}$ & $\pm 678.2^{\mathrm{a}}$ & $\pm 442.70^{\mathrm{a}}$ \\
Motility score & 3.7 & 3.4 & 3.4 \\
Testosterone level & $\pm 1.1^{\mathrm{a}}$ & $\pm 0.5^{\mathrm{a}}$ & $\pm 0.5^{\mathrm{a}}$ \\
$(\mathrm{ng} / \mathrm{mL})$ & 10.2 & 18.51 & 29.57 \\
\hline
\end{tabular}

$\left({ }^{\mathrm{a}, \mathrm{b}, \mathrm{c}}\right)$ : Different superscript in the same row shows significant differences $(\mathrm{P}<0.05)$.
The spermatozoa motility score in $\mathrm{P} 0, \mathrm{P} 1$, and $\mathrm{P} 2$ were $3.7 \pm 1.1 ; 3.4 \pm 0.5$; and $3.4 \pm 0.5$, respectively. Based on statistical tests, the administration of PGF2 $\alpha$ and EVS have no effect on sperm motility $(\mathrm{P}>0.05)$. The tendency of declining spermatozoa motility in this study may be due to differences in the semen collection method. Decreased motility after administration of PGF $2 \alpha$ not only occurs in kacang goat but could also occur in other animals. This is in accordance with the statement of Capitan et al. (1990), Masoumi et al. (2011), and Olfati et al. (2013). Capitan et al. (1990) reported the motility of buffalo spermatozoa pretreatment, in treatment, and post- treatment were 43.19\%; 45.46\%; and 49.06\%. Masoumi et al. (2011) reported that mean spermatozoa motility induced with PGF $2 \alpha$ vs control were $53.9 \pm 1.6$ vs $51.9 \pm 1.6 \%$ and $36.1 \pm 0.6$ vs $35.6 \pm 0.7 \%$, respectively. Olfati et al. (2013) reported a comparison of sheep spermatozoa motility between groups given PGF $2 \alpha$ with controls were $67.8 \pm 11.3$ and $65.1 \pm 10.6 \%$, respectively.

Decline in sperm motility after PGF2 $\alpha$ administration was not only observed in vivo but also reported in vitro. Karahan et al. (2006) explained that supplementation of 500 and $1000 \mu \mathrm{g}$ PGF2 $\alpha$ caused spermatozoa motility to decline significantly after four hours, while addition of $1,500 \mu \mathrm{g}$ PGF2 $\alpha$ in diluted cattle semen decreased spermatozoa motility after two hours compared with diluted cattle semen without PGF2 $\alpha$ $(\mathrm{P}<0.05)$ in vitro.

The tendency of declining sperm motility in this study could not be theoretically explained because PGF2 $\alpha$ and EVS are supposed to increase sperm motility. Mechanism of increased motility in EVS administration is assumed similar to that of PGF2 $\alpha$ administration. According to Schlegel et al. (1981), PGF2 $\alpha$ plays role in improving sperm motility. Inactivation of PGF $2 \alpha$ in sperm through incubation with prostaglandin 15-hydroxydehydrogenase resulted in decreased sperm motility. Herawati and Widiarso (2003) reported that the addition of $2.0 \mathrm{mg}$ PGF $2 \alpha$ before dilution may increase motility of goat spermatozoa. The increased spermatozoa motility is due to PGF $2 \alpha$ activates the contractile element of spermatozoa that is the layer of fibers that surrounds the central acronema of main body of spermatozoa.

The results showed that administration of PGF $2 \alpha$ and EVS increase testosterone levels of kacang goat $(\mathrm{P}<0.05)$. Testosterone levels (mean $\pm \mathrm{SD}$ ) levels of kacang goat in $\mathrm{P} 0, \mathrm{P} 1$, and $\mathrm{P} 2$ were $10.27 \pm 5.42$, $18.51 \pm 19.46$, and $29.57 \pm 12.96 \mathrm{ng} / \mathrm{mL}$, respectively. The results are in accordance with Kiser et al. (1976) and Saifudini et al. (2005) that stated PGF2 $\alpha$ may increase testosterone levels of cow and sheep. Testosterone levels found in this study were much higher (and $29.57 \pm 12.96 \mathrm{ng} / \mathrm{mL}$ ) than those found in previous study conducted by Masoumi et al. (2011) in 
Holstein cow injected with PGF2 $\alpha(4.1 \pm 0.6 \mathrm{ng} / \mathrm{mL})$. On the contrary, Siregar et al. (2014) reported different result in which administration of PGF $2 \alpha$ and EVS tends to decrease the testosterone levels of white mouse. Varied results are likely due to the difference in animal species used in each study.

The mechanism of increased testosterone due to PGF2 $\alpha$ is most likely via direct action on testes, i.e. through stimulation of cyclic AMP production in testes (Haynes et al., 1975). Cyclic AMP then stimulates the synthesis of testosterone (Reichard et al., 1978). In seminal vesicles secretion, several enzymes play a role in biosynthesis of PGF2 $\alpha$ such as prostaglandin endoperoxidase reductase enzyme which reduce 2 electrons in prostaglandin $\mathrm{H} 2$ and transform it to PGF2 $\alpha$ (Burgess and Reddy, 1997).

Testosterone secreted by Leydig cells has a reciprocal effect in inhibiting LH secretion. These effects primarily inhibit GnRH secretion by the hypothalamus and lead to decline in $\mathrm{LH}$ and $\mathrm{FSH}$. When testosterone level decreases, the hypothalamus will increase GnRH secretion and cause secretion of $\mathrm{LH}$ and FSH to increase, which will be followed by increased testosterone production by the testes (Weinbauer et al., 2000).

Factors affecting animal testosterone levels in the blood are nation of origin, age, environment, disease, presence or absence of sexual stimulation, and the sensitivity of the methods. Variations in testosterone levels of kacang goats in this study may be caused by stress factors during blood sampling. Animals experiencing stress have an increase in cortisol level in the blood that was negatively correlated with testosterone. When cortisol levels rise, testosterone levels will decrease. Furthermore, centrifuging blood samples after 24 hours may also significantly decrease testosterone levels as previously observed by Abdilla (2015)

As conclusion, this study found that EVS administration did not increase spermatozoa concentration and motility but increased testosterone level of kacang goats.

\section{Conflict of interest}

The authors declare that there is no conflict of interest.

\section{References}

Abdilla, A. 2015. Teknik Preparasi dan Penyimpanan Sampel Darah Kambing Kacang untuk Analisis Hormon Testosteron Menggunakan Metode ELISA. Thesis. Fakultas Kedokteran Hewan Universitas Syiah Kuala. Banda Aceh.

Burgess, J.R. and Reddy, C.C. 1997. Isolation and characterization of enzyme from sheep seminal vesicles that catalyzes the glutathion-dependent reduction of prostaglandin $\mathrm{h}_{2}$ to prostaglandin $\mathrm{F} 2 \alpha$. Biochem. Mol. Biol. Int. 41, 217-226.
Capitan, S.S., Antiporda, G.S. and Momongan, V.G. 1990. Reaction time, semen output and semen quality of buffalo bulls after pre-collection injection of prostaglandin F2 alpha (PGF2 alpha). AsianAustralas J. Anim. Sci. 3(4), 343-346.

Cornwall, G.A. 2009. New insight into epididymal biology and function. Hum. Reprod. Update 15, 213-227.

Estienne, M.J. and Harper, A.F. 2004. Semen characteristics and libido in boars treated repeatedly with PGF2 $\alpha$. J. Anim. Sci. 82, 1494-1498.

Gonzales, G.F. 2001. Function of seminal vesicles and their role on male fertility. Asian J. Androl. 3, 251258.

Hafez, E.S.E. 2000. Anatomy of Male Reproduction. In: Reproduction in Farm Animals. $7^{\text {th }}$ ed. Lippincott William \& Wilkins, Philadelphia.

Hafs, H.D., Louis, T.M. and Stellflug, J.N. 1974. Increased sperm numbers in the deferent duct after PGF2 alfa in rabbits. Proc. Soc. Exp. Biol. Med. 145, 11-20.

Hanum, A.N., Setiatin, E.N., Samsudewa, D., Kurnianto, E., Purbowati, E. and Sutopo, S. 2012. Perbandingan kualitas semen kambing kejobong dan kambing kacang di Jawa Tengah. Prosiding Seminar Nasional Peternakan Berkelanjutan 4, 7 November 2012, Fakultas Peternakan Universitas Padjadjaran Jatinangor-Bandung.

Hashizume, T. and Niwa, T. 1984. Effect of administration of Prostaglandin F2 $\alpha$ on the properties of sperm rich fraction on boar semen. Japan. J. Anim. Reprod. 39, 182-185.

Haynes, N.B., Hafs, H.D., Water, R.J., Manns, J.G. and Railey, A. 1975. Stimulatory effect of prostaglandin $\mathrm{F} 2 \alpha$ on the plasma concentration. Bull. J. Endocrinol. 66, 329-338.

Herawati and Widiarso, B.P. 2003. Pengaruh penambahan prostaglandin F2 $\alpha$ terhadap kualitas sperma pada semen kambing yang diencerkan dengan berbagai larutan. J. Indon. Trop. Anim. Agric. 28(2), 74-78.

Hess, M. 2002. The Effects of Prostaglandin F2 $\alpha$, Oxytocin and Gonadotropin Releasing Hormone on Ejaculate Characteristics in The Dog. Thesis. Virginia Polytechnic Institute and State University, Virginia.

Karahan, I., Gaffari, T. and Seyfettin, T. 2006. In vitro effects of prostaglandin F2 $\alpha$ and metamizol on the motility of diluted bull semen. Turk. J. Vet. Anim. Sci. 30, 271-278.

Kiser, T.E., Hafs, H.D. and Oxender, W.D. 1976. Increased blood $\mathrm{LH}$ and testosteron after administration PGF2 $\alpha$ in bulls. Prostaglandins 2, 543-553.

Kreider, J.L., Ogg, W.L. and Turner, J.W. 1981. Influence of prostaglandin F2 alpha on sperm 
production and seminal characteristics of the stallion. Prostaglandins 22(6), 903-908.

Lessard, C., Parent, S., Leclerc, P., Bailey, J.L. and Sullivan, R. 2000. Cryopreservation alters the levels of the bull sperm surface protein P25b. J. Androl. 21, 700-707.

Masoumi, R., Towhidi, A., Javaremi, A.N., Nabizadeh, H. and Zhandi, M. 2011. Influence of PGF2 $\alpha$ on semen quality and libido in Holstein bulls. Turk. J. Vet. Anim. Sci. 35(1), 1-6.

Mekonnen, G., Boland, M. and Gordon, I. 1989. Effect of prostaglandin on semen production and libido in the ram. Irish Vet. J. 42, 56-59.

Olfati, A., Moghaddam, G.H., Kia, H.D. and Shabankareh, H.K. 2013. Effects of prostaglandin F2 $\alpha$ treatment on semen characteristics of crossbred rams in the non-breeding season. J. Cell Anim. Biol. $7(2), 16-20$.

Pamungkas, F.A., Mahmilia, F. and Eliesier, S. 2008. The comparative characteristics of boer and kacang goat semen. Prosiding Seminar Nasional Teknologi Peternakan dan Veteriner, 367-370.

Pemayun, T.G.O., Mahaputra, L., Ismudiono, and Soetjipto. 2008. Penurunan kadar progesteron kuda fase luteal setelah pemberian prostaglandin F2 $\alpha$ hasil ekstraksi vesikula seminalis sapi Bali. J. Vet. 9(4), 163-167.

Rachmawati, L., Ismaya, I. and Panjono, P. 2011. Perbandingan kuantitas dan kualitas sperma kambing kacang, kejobong, dan peranakan Etawah. Prosiding Seminar Nasional Prospek dan Potensi Sumberdaya Ternak Lokal dalam Menunjang Ketahanan Pangan Hewani. Fakultas Peternakan Universitas Jenderal Sudirman, Purwokerto, 509518.

Reichard, L.A., Hafs, H.D., Haynes, N.B., Collier, R.J.,
Kiser, T.E. and McCarthy, M.S. 1978. Sperm output and serum testosterone in rabbits given prostaglandin F2 $\alpha$ or E2. Prostaglandins 16(1), 135142.

Saifudini, M., Soebagyo, S. and Putro, P.P. 2005. Pengaruh pemberian prostaglandin F2 alpha (PGF2 $\alpha$ ) terhadap kualitas semen dan kadar testosteron domba lokal. Agrosains 18(4).

Schlegel, W., Rotermund, S., Färber, G. and Nieschlag, E. 1981. The influence of prostaglandins on sperm motility. Prostaglandins 21(1), 87-99.

Sherwood, L. 1995. Human Physiology from Cells to Systems. $2^{\text {nd }}$ ed. West Publishing Company, San Fransisco.

Siregar, T.N., Akmal, A., Wahyuni, S., Tarigan, H., Mulyadi, and Nasution, I. 2014. Pemberian ekstrak vesikula seminalis meningkatkan kualitas spermatozoa tetapi tidak memengaruhi konsentrasi spermatozoa dan testosterone tikus putih. J. Ked. Hewan. 8(2), 90-93.

Syafruddin, S., Siregar, T.N., Herrialfian, H., Armansyah, T., Sayuti, A. and Roslizawaty, R. 2010. The efficacy of seminal vesicles extract administration on percentage of estrus and pregnancy on local goat. J. Ked. Hewan. 4(2), 5360.

Toelihere, M.R. 1985. Fisiologi Reproduksi pada Ternak. Angkasa, Bandung.

Traas, A.M. and Kustritz, M.V.R. 2004. Effect of administrating oxytocin or prostaglandin F2 $\alpha$ on characteristics of the canine ejaculate. Can. Vet. J. 45(12), 999-1002.

Weinbauer, G.F., Gromoll, J., Simoni, M. and Nieschlag, E. 2000. Andrology: Male Reproductive Health and Dysfunction. $2^{\text {nd }}$ ed. Springer, New York. 